\title{
Business model based on community for a sustainable tourism development
}

\author{
Ionela Samuil ${ }^{1 *}$, Andreea Cristina Ionică ${ }^{1}$ \\ ${ }^{1}$ University of Petrosani, Str. Universitatii nr.20, Petrosani, Romania
}

\begin{abstract}
Improper management practices in tourism can have an undesirable impact on the environment and society and can threaten both the development of tourism and the economic viability of communities. Awareness of this challenge has led to widespread acceptance of the concept of sustainable development. The purpose of this paper is to highlight that sustainable development is achieved with the support and participation of all parties involved in tourism. As tourism is promoted as a tool for community conservation and development, the emphasis must be on local communities and their needs and capacities. If well designed, community-based tourism can become a mechanism for reducing poverty and improving the quality of life, providing economic benefits to people in local communities. The objective of this research is to highlight the importance of collaboration actions between authorities, stakeholders and the community for the development of the Petrila Theme Park. Also, based on social and technicaleconomic studies, a business model will be proposed to allow the visualization of the potential impacts generated by the development of tourism.
\end{abstract}

\section{Introduction}

As an alternative to past industrial activities in the city of Petrila, we seek to understand the role, responsibilities and benefits of the most important actors in a tourist destination, in sustainable tourism practice and policy, and how they are involved in the process of its adoption and implementation. The aim is to understand the premises underlying the development of tourism in the area, depending on the main stakeholders, focusing mainly on the challenges and, most importantly, on proposing a business model that leads to obtaining the best results.

In the first part of the paper there is a review of different views on the concepts covered, depending on the field of study of researchers. The second part includes the results of two preliminary studies, namely: the technical-economic study and the sociological research carried out among the inhabitants of Petrila, Jiu Valley. The technical-economic study presents the works carried out for the closure and safety of the mine but also the costs of consolidation, redevelopment and maintenance of buildings, in relation to the future destination of each construction and the works necessary to be carried out for the proposed purpose. Sociological research aims to identify what their perspective is in relation to the

\footnotetext{
* Corresponding author: ionelasamuil@upet.ro
} 
development of tourism in the area, as an alternative to industrial activities carried out in the past. The results of the preliminary studies are capitalized in a business model, with the involvement of the community, in which residents are considered key stakeholders, along with local public authorities and other stakeholders. The third part presents the conclusions and discussions on future study directions.

\section{Literature review}

\subsection{Sustainable development, tourism and social participation for sustainability}

Although there are many definitions of sustainable tourism [1], they all have three common key principles that help us understand what the basic directions of any sustainable tourism initiative should be, namely economic, ecological and socio-cultural aspects [2]. Tourism development is sustainable: ecological if it does not oppose the processes and ecological development of the area, economically if it is seen as an investment in the development of the region, aiming to build and manage the productive base needed to support future generations and socio-cultural if it incorporates participation community decision-making and strategic development [3].

In the volatile economic conditions generated by globalization, development can only be sustained by improving competitiveness, requiring a high quality of environmental protection policies among the various actors involved in tourism activities, no longer sufficient economic efficiency. As tourism companies become an important part of the global economy, collaboration actions at the local level also increase in importance [4]. Of these, those focused on quality and environmental protection are crucial for the development of sustainable tourism [5-7] as not all environmental problems can be solved only through regulations, sometimes requiring the involvement of a range large organizations in the public, private, and nonprofit sectors [8-9].

The development of tourism requires the development of a complex policy, because the interaction between actors is never free from conflicts arising from divergent and / or opposite interests [10] generated by the unequal distribution of influence between stakeholders. Communication and dialogue between stakeholders are essential, and the analysis and recognition of these tensions is a valuable methodological focus for the realization of legitimate and socially sustainable tourism development projects [11].

Little attention has been paid to investigating the roles and responsibilities of local government in addressing sustainable development within a tourist destination [12-13]. However, the authorities have a critical role to play in creating the context and stimulating actions for the development of tourism on the principle of sustainability.

The success of sustainable development is based in part on the support and participation of stakeholders in tourism. Although not all stakeholders need to be equally involved in decision-making associated with sustainable development, all their interests need to be identified and understood [14]. If the interests of a key stakeholder group are not identified, then the whole process may fail [15].

It is obvious that for the successful development of tourism in an area, it is also necessary to obtain a positive attitude of the locals towards this action and the active involvement of the host community. Studies that follow the reactions of the local population to the idea of tourism development can help planners understand why the inhabitants of an area support or, on the contrary, oppose specific actions for tourism development. Based on the results, the optimal development directions can be selected to minimize the negative impact on the area 
and maximize support among members of the local population for tourism development [1617].

\subsection{Economically sustainable and socially responsible growth}

In modern society, the main vectors or forces that act for the sustainable development of tourism are the social, environmental and economic vectors (figure 1). According to this model, society is divided into three major groups called "dimensions":

- social: elements related to health, knowledge, training, culture, etc;

- environmental: natural resources, environmental quality, biological diversity, etc;

- economic: technology, real estate, financial means, etc.

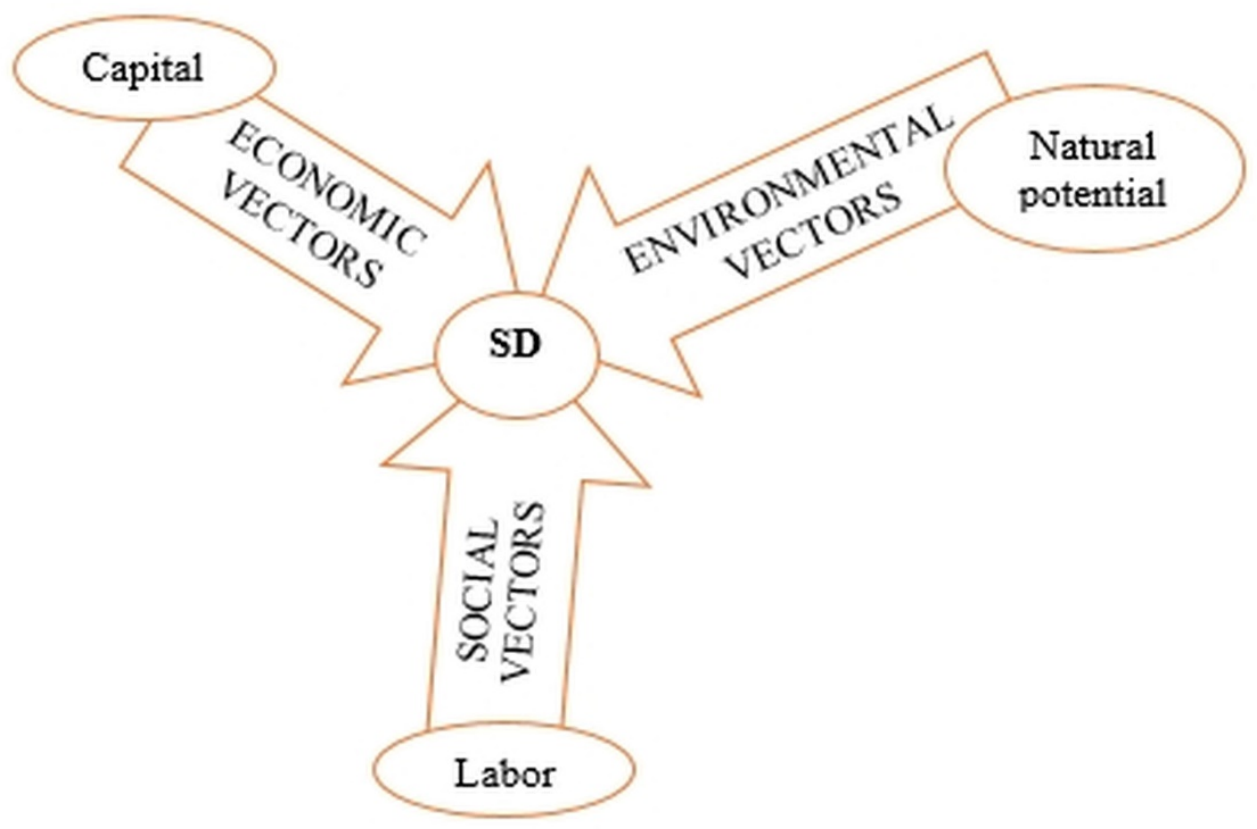

Fig. 1. Vectors for a sustainable development (SD)

Sustainable development aims to maintain a balance between these three dimensions, both locally and nationally and internationally. Recently, a fourth dimension on the preservation of cultural heritage and traditions has been added to the three dimensions. If until a few decades ago it was considered that most of the added value belongs to the factor of production - capital (economic vector), now there is a shift of emphasis to the other two. The most important pillar of the sustainable economy concerns the main factor of production - man (social vector) but assumes that the added value includes a series of expenses generated by compliance with environmental standards (environmental vector), as well as greater social responsibility of the company.

Competitiveness refers not only to the economic performance of a nation, but also to the social and environmental performance. The synergy between these three dimensions of performance is the path to sustainable competitiveness [18].

The concept of sustainable development is used in different sectors of the economy and it is perfectly logical that it is also introduced in the tourism sector, given that it can have social, environmental and economic consequences in the host regions. Taking into account 
the foundation of sustainable development, it is necessary that the objectives of sustainable tourism be developed in all three directions (Table 1).

Table 1. The objectives of sustainable tourism

\begin{tabular}{|c|c|}
\hline & OBJECTIVES \\
\hline \multirow{4}{*}{ SOCIAI } & $\begin{array}{l}\text { Improving the quality of life (greater accessibility to recreational and sports activities, increasing } \\
\text { accessibility to cultural and leisure activities); }\end{array}$ \\
\hline & $\begin{array}{l}\text { Better knowledge of other cultures and communities (mutual knowledge, in the relationship } \\
\text { between the local population - tourists in the process of their interaction, promotes } \\
\text { communication); }\end{array}$ \\
\hline & $\begin{array}{l}\text { Increasing the sense of pride in belonging to the area (the heritage of an area refers not only to } \\
\text { the monuments and artifacts that remain, although important, but also to the people and } \\
\text { communities that have used their lives and energy to create the habitats in which they live); }\end{array}$ \\
\hline & $\begin{array}{l}\text { Improving services (restaurants, shops and hotels in the ares, services provided by police and } \\
\text { firefighters). }\end{array}$ \\
\hline \multirow[b]{4}{*}{ ENVIRONMIENTAL } & $\begin{array}{l}\text { Better protection of the entironment (strengthening ecosystem resilience helps maintain } \\
\text { productivity and quality of life while reducing public health spending); }\end{array}$ \\
\hline & Improving infrastructure (water supply, electricity, telephone services, etc.) \\
\hline & Rehabilitation and extension of roads but also improvement of other public services; \\
\hline & $\begin{array}{l}\text { More support for the restoration and maintenance of historic buildings (historic buildings are } \\
\text { components of history and culture, proof of the art of construction in the past and give us a } \\
\text { cultural identity). }\end{array}$ \\
\hline \multirow{5}{*}{ ECONOMIC } & $\begin{array}{l}\text { Increasing investment and development of the area (increasing the competitiveness of the region } \\
\text { and ensuring long-term viability); }\end{array}$ \\
\hline & $\begin{array}{l}\text { Increasing employment opportunities (increasing the number of tourism-induced jobs for the } \\
\text { local population); }\end{array}$ \\
\hline & $\begin{array}{l}\text { Contributions to improving incomes and living standards (increasing income, improving the } \\
\text { working environment and employment opportunities; }\end{array}$ \\
\hline & Contributions to the local budget (the local budget increases by collecting taxes); \\
\hline & $\begin{array}{l}\text { Equity (providing the framework for the distribution of economic benefits, especially to the local } \\
\text { population). }\end{array}$ \\
\hline
\end{tabular}

\subsection{The importance of business model}

With the development of information and communication technologies, in the 1990s, a shortterm fascination for the business model concept emerged. At that time, however, it failed to settle economic forces and not only, as the continuous transformation, technological changes, globalization and sustainability policies rekindled interest in this concept. Recent technological and communication advances have highlighted the rise of the importance of achieving a business model, which is considered fundamental for any organization.

According to Bocken et al. [19] "companies can use one or a selection of business model archetypes to carry out their own transformation, they are designed to assist in exploring new ways to create and deliver sustainable value, and to develop the structure of the business model, providing guidance to realize the new opportunities".

However, despite the interest in the WB concept, researchers do not agree on a common definition and vocabulary, and therefore there are an abundance of definitions that differ depending on their scope (Table 2).

Also, the components of the business model are not yet well clarified in the literature due to the fact that researchers who have proposed various conceptualizations of the term come from various fields such as eBusiness and eCommerce, strategies, business management, economics and technology and have approached research accordingly [20,21].

To summarize, a business model is not a simple description of what the firm does, but should be a complex characterization that captures the essence of cause-and-effect relationships between stakeholders and money [22]. 
Table 2. Approaches to the BM concept

\begin{tabular}{|c|c|}
\hline Author & Conceptualization \\
\hline $\begin{array}{l}\text { Vonkatranan \& } \\
\text { Henderson }(1998)\end{array}$ & $\begin{array}{l}\text { A strategy that reflects the architecture of an organization along three main vectors: customer } \\
\text { interaction, assat configuration, and lenowledge leverage. }\end{array}$ \\
\hline $\begin{array}{c}\text { Linder \& Cantrell } \\
(2000)\end{array}$ & The basic logic of the organization for value creation and explains how it makes money. \\
\hline $\begin{array}{l}\text { Petrovic ot al. } \\
\text { (2001) }\end{array}$ & $\begin{array}{l}\text { A description of the value that a company offers to one or more customer segments, the architecture } \\
\text { of the company and its network of partners for the creation, marketing and delivery of this value as } \\
\text { well as capital relationships to generate profit and gustainable revenue streams. }\end{array}$ \\
\hline Stahier (2002) & $\begin{array}{l}\text { A simplification of the complex reality and helps to understand the basics of an existing business } \\
\text { or to plan how a future business ghould look like. }\end{array}$ \\
\hline $\begin{array}{l}\text { Compansovio \& } \\
\text { Pigsew (2003) }\end{array}$ & $\begin{array}{l}\text { A detailed conceptualization of the strategy of an enterprise at an abstract level, which gerves as a } \\
\text { basis for the implementation of business processes. }\end{array}$ \\
\hline Leem at al. (2004) & $\begin{array}{l}\text { A set of strategies for corporate establishment and management, including an revenue model, high- } \\
\text { level business processes and alliances. }\end{array}$ \\
\hline Shaffer et ai. (2005) & $\begin{array}{l}\text { Representing the logic and basic strategic choices of a company to create and capture value in a } \\
\text { network of values. }\end{array}$ \\
\hline Kailio et al. (2000) & $\begin{array}{l}\text { The means by which a firm is able to create value by coordinating the flow of information, goods } \\
\text { and services between the various participants in the industry with which it comes into contact, with } \\
\text { cuatomers, value chain partmers, competitors and govemment. }\end{array}$ \\
\hline $\begin{array}{c}\text { Rajaia \& } \\
\text { W6sterivend (2007) }\end{array}$ & $\begin{array}{l}\text { Ways to create value for customers and how a business tums market opportumities into profit } \\
\text { through actors, activities and collaborations. }\end{array}$ \\
\hline $\begin{array}{l}\text { Al-Debsi et ai. } \\
\quad(2008)\end{array}$ & $\begin{array}{l}\text { An abstract representation of an organization, whether conceptual, textual, and / or graphic, of all } \\
\text { interrelated architectural, cooperation, and financial arrangements designed and developed by an } \\
\text { organization now and in the future, as well as all commodities and / or gervices that the organization } \\
\text { provides or will provide them, based on those arrangements that are necesgary to achieve its } \\
\text { objectives and gtrategic objectives. }\end{array}$ \\
\hline Johyson (2010) & $\begin{array}{l}\text { Centralization of four elements through which companies create value - the proposal of values, the } \\
\text { system of value creation, the release of values and the model of capturing values. }\end{array}$ \\
\hline $\begin{array}{l}\text { Tein \& Nhooval } \\
\text { (2013) }\end{array}$ & $\begin{array}{l}\text { An essential tool for commercializing scientific innovation, creating strategic flexibility, reducing } \\
\text { costs and the ability to overcome the constraints faced by different societies. }\end{array}$ \\
\hline $\begin{array}{c}\text { Abdelkafi \& } \\
\text { Täuscher }(2010)\end{array}$ & Managerial tool that refers to how value is created, delivered and captured. \\
\hline
\end{tabular}

I noticed, studying the literature that the most popular business model is Canvas, usually comprising nine value propositions: key partners, key activities, key resources, value-added suppliers, customer relations, distribution channels, cost structure , customer segments, sources of income. Osterwalder \& Pigneur [23] consider that all these grouped components make it possible to visualize the value and performance of the business model.

However, static business models are generally criticized for their rigidity and therefore dynamic business models are often developed that are an alternative in a turbulent economic environment [24]. The realization of dynamic business models is performed by combining conventional business model schemes [25] with modeling the dynamics of the system.

Few studies have focused on tourism business models, which is certainly surprising, given the importance of this industry in the world economy. The literature mainly refers to ebusiness models and travel agencies [26-29] which is understandable up to a point given the significant influence that the internet has had over the last 20 years.

\section{Materials and methods}

Issues such as the potential for the restoration of buildings from a technical point of view, as well as the perceptions of locals regarding the development of IHT are treated as preliminary studies. The results of these studies were important for shaping a business model with community involvement and the logical flow of processes is presented in Figure 2. 


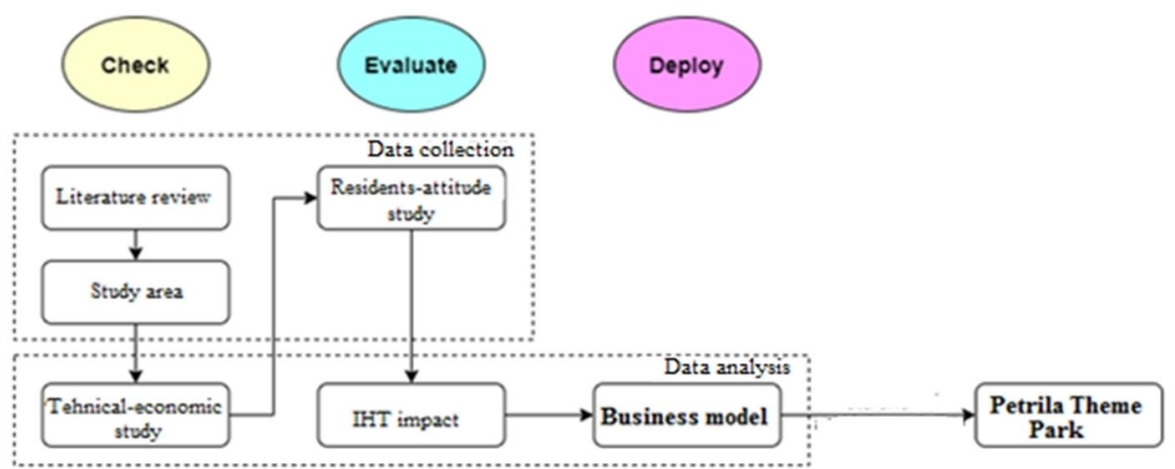

Fig. 2. Business model for Petrila Theme Park

\subsection{Study area}

Petrila Mine is the oldest and deepest mine in the Jiu Valley, now closed, the deadline for completion of coal extraction, provided in the Closure Plan, being on December 31, 2015. At one time it was the most modern and complex coal mine in this area. The buildings that make up the industrial area are a real lesson in the history of mining, representing a sample of industrial archeology.

In order to determine the fair, market value of land, buildings, classified by Order of the Ministry of Culture no. 2823/21.12.2015, as historical monuments, with annexes and equipment belonging to them, as well as constructions located in the protection area of historical monuments, which are part of the Mina Petrila Ensemble and their related lands that belonged to the Mina Petrila Branch and which were decommissioned, the procedures for valuing these assets were started. After the completion of the evaluation procedures, their tabulation follows in order to start the procedure of capitalization through sale [30].

The Petrila mine, according to the initial plan, was to be completely demolished and in its place, the land had to be sown with grass. A group of architects and volunteers showed, however, that the recovery of the area can be done by invigorating these buildings and even found money for funding.

The Petrila mine carries out the most extensive actions for the regeneration of the industrial heritage through cultural actions, aiming at the reconversion of the former Petrila mining operation into the cultural, administrative and economic center of the city. In this sense, the first steps are achieved by organizing small cultural and community events that will increase over time and could support attracting funds for the conversion of the entire site [31].

In 2018, a meeting was held concerning the future of the Petrila mine, attended by representatives of Petrila City Hall, SNIM VJ, RUR coordinator for the city's P.U.G., local and national civil society representatives and experts in European funds. At the end of the meeting, a declaration of commitment was signed which includes four essential points in the evolution of the approach, including the establishment of the "Planeta Petrila Association", with founding members: Petrila City Hall, Plusminus Association, Ideilagram Association, ACV Petroşani and contribution, including financial, of the City Hall of Petrila to the shortterm action plan. 


\subsection{Tehnical economic study}

A technical-economic study was also done and a review of the works carried out for the safe closure of the mine. According to the Administration Activity Report (2018), based on the approved works schedule, all decommissioning / demolition and greening works have been completed. Closure and greening works were carried out to mitigate the impact on the environment caused by the closure of the mine, respectively: securing the underground; rehabilitation of mining premises; recultivation of land areas that have been used in mining.

The conclusion is that these works are stable and there is no danger of affecting the stability of the surface, respectively of the constructions located in the perimeter that is the object of the present study. The part of the buildings involves the works of consolidation of the foundations and exterior surfaces, respectively the works of redevelopment of the interior space in order that they are foreseen by the project of social and economic development of the site.

For the tehnical study were used qualitative research methods: documentation and quantitative research methods: Tools: WinDocDeviz

\subsection{The attitude of the locals study}

One of the solutions for the reconversion of the industrial patrimony in the Jiu Valley, more and more often brought into discussion, refers to the transformation of the former mining units into tourist objectives, in order to reintegrate these spaces in the economic circuit. In this sense, in 2020, a social study was conducted [32] in order to identify the attitude of the inhabitants of Petrila towards the development of post-industrial tourism, as an alternative to industrial activities but, especially, to what extent they are willing to get involved in order to materialize. In addition, the availability of the locals in order to transform the former Petrila mining perimeter into a theme park, their vision regarding the new destinations for the existing buildings, the inclusion of the park in a tourist circuit along with the other natural and anthropic attractions in the area. technologies for its promotion.

For evaluating the attitude of the inhabitant's, qualitative research methods were used: the observation method and also, quantitative research methods: Tools: questionnaire technique - Questionnaire for determining the attitude of locals in relation to the development of tourism in the area (using the model proposed by Ko \& Steward [33] and taken over by Vargas-Sanchez [34]).

\section{Business model based on community involvement for the realization of the Petrila Theme Park}

\subsection{Premises of the design of a BM for the development of sustainable tourism in the post-industrial perimeter}

The potential positive effects to be registered following the development of tourism activities in the area have a major influence in determining a positive attitude among locals, being identified availability to support measures to develop tourism activities in the area.

The reliability analysis demonstrates consistency, with the Cronbach alfa index exceeding the minimum level of 0.70 set by Nunnally and Bernstein [35] (tables 3).

From an economic point of view, the most concrete positive effects, are to be found in the labor market, as a result of the increase of employment opportunities. At the social and cultural level, the most important positive effect is materialized in the increase of the feeling of belonging to the area, materialized by including the inhabitants in the development 
process, they will become part of the whole. Environmental policies will be felt, especially by increasing the quality of road structure but also by improving other public services.

Table 3. Reliability of the scales for determining the positive impact of tourism development

\begin{tabular}{|c|c|c|c|}
\hline Variables & Mean (SD) & $\begin{array}{l}\text { Items-total } \\
\text { correlation }\end{array}$ & $\begin{array}{l}\text { Alpha } \\
\text { if Item } \\
\text { Deleted }\end{array}$ \\
\hline \multicolumn{4}{|l|}{ Economic impect } \\
\hline Increasing investments & $4.29(0.745)$ & 0.554 & 0.826 \\
\hline Development of the area & $4.42(0.716)$ & 0.471 & 0.831 \\
\hline Improving infrastructure & $4.26(0.769)$ & 0.553 & 0.826 \\
\hline Increasing employment opportumities & $4.37(0.771)$ & 0.509 & 0.829 \\
\hline Contributions to improving incomes and living standards & $4.21(0.865)$ & 0.525 & 0.828 \\
\hline Increasing revenues to local budgets, due to taxes collected & $4.31(0.794)$ & 0.338 & 0.838 \\
\hline \multicolumn{4}{|l|}{ Social and cultur al impact } \\
\hline Improving the quality of life & $4.23(0.735)$ & 0.557 & 0.826 \\
\hline Greater accessibility to recreational and sports activities & $4.42(0.691)$ & 0.352 & 0.837 \\
\hline Better knowledge of other cultures and communities & $4.27(0.765)$ & 0.508 & 0.829 \\
\hline Increasing the demand for cultural and leisure activities & $4.46(0.626)$ & 0.504 & 0.830 \\
\hline Providing providers of cultural and leigure activities & $4.46(0.675)$ & 0.520 & 0.829 \\
\hline Increasing the feeling of pride regarding belonging to the area & $4.49(0.657)$ & 0.525 & 0.828 \\
\hline Improving services in restaurants, hotels and shops in the area & $4.46(0.636)$ & 0.331 & 0.837 \\
\hline Improving the services offered by the police and fire brigades & $4.13(0.851)$ & 0.307 & 0.841 \\
\hline \multicolumn{4}{|l|}{ Impact on the environment } \\
\hline Better protection of the environment & $4.47(0.550)$ & 0.129 & 0.845 \\
\hline Infrastructure improvement (water supply, electricity; telephone services) & $4.50(0.527)$ & 0.397 & 0.835 \\
\hline Arranging roads and improving other public services & $4.54(0.537)$ & 0.468 & 0.832 \\
\hline More support for the restoration and maintenance of historic buil & $4.51(0.585)$ & 0.282 & 0.839 \\
\hline
\end{tabular}

The obtained results showed that the possible negative effects that could derive from the development of tourism activities are not influencing factors in determining the attitude of the inhabitants of the area in this regard. The opinion of the inhabitants is that, there will be benefits in all sectors, by placing the area on the tourist map and the general satisfaction of the community can be obtained, as a result of these actions.

\subsection{Canvas Business Model - Petrila Theme Park}

Analyzing the possibility of recovering the industrial heritage, we find that reuse is at least as expensive as replacement. However, the old buildings in question have a special charm, a quality that is difficult to define that makes them very attractive for a certain segment of the public. The precarious economic situation of many companies with industrial assets causes them to either abandon or sell assets whose maintenance is too expensive, or to "refunctionalize" them, with cheap and low-quality destructive investments, to rent it.

The obtained results provide the framework for proposing a business model with the involvement of the community in order to transform the former Petrila mining complex into a theme park (fig.3). The development and operation of the Petrila Theme Park, included in a tourist circuit will generate a series of positive effects materialized in increasing the number of jobs, improving living conditions, changing the image of the area for both locals and visitors, a greater concern for improving environmental protection policies, etc. but also obtaining a general satisfaction of the community.

The importance of community participation in development has increased since the 1970s due to the recognition of its contribution to the success of projects [36-37]. In the literature on tourism activities, emphasis has been placed on local communities and their needs and capacities [38-39] because tourism is promoted as a tool for community conservation and development. 


\begin{tabular}{|c|c|c|c|c|}
\hline Key Partners & Key Activities & \multirow{3}{*}{$\begin{array}{l}\text { Value Propositions } \\
\text { - Revaluation of industrial } \\
\text { spaces with the help of } \\
\text { tourism and their } \\
\text { reintroduction into the } \\
\text { economic circuit. } \\
\text { - Increasing the level of } \\
\text { attractiveness of the area. } \\
\text { - Improving the standard } \\
\text { of living of the } \\
\text { inhabitants by creating } \\
\text { new jobs and increasing } \\
\text { incomes. } \\
\text { - Achieving overall } \\
\text { community satisfaction by } \\
\text { improving infrastructure } \\
\text { and other services. } \\
\text { - Increasing the level of } \\
\text { taxes collected in the } \\
\text { local budget. }\end{array}$} & Customer Relationships & Customer Segments \\
\hline \multirow[t]{2}{*}{$\begin{array}{l}\text { - Local authorities } \\
\text { - Stakeholders } \\
\text { - Community }\end{array}$} & 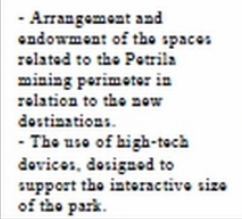 & & $\begin{array}{l}\text { - Promotion through } \\
\text { travel agencies. } \\
\text { - Organizing cultural } \\
\text { events with the } \\
\text { participation of artists. }\end{array}$ & \multirow[t]{2}{*}{$\begin{array}{l}\text { - Active people } \\
\text { interested in various } \\
\text { forms of tourism such } \\
\text { as: heritage. post- } \\
\text { industrial tourism. } \\
\text { adventure tourism. } \\
\text { natural or all connected } \\
\text { in a circuit. } \\
\text { - Artists interested in } \\
\text { the cultural heritage of } \\
\text { the area. }\end{array}$} \\
\hline & $\begin{array}{l}\text { Key Resources } \\
\text { - Heritage elements } \\
\text { included in the National } \\
\text { Heritage list. } \\
\text { - Qualified staff. } \\
\text { - Shows and concerts } \\
\text { organized for children } \\
\text { and young people. } \\
\text { - Individual and family } \\
\text { programs. }\end{array}$ & & $\begin{array}{l}\text { Channels } \\
\text { - Communication and } \\
\text { distribution through } \\
\text { social and media } \\
\text { platforms. } \\
\text { - Creation of leaflets. } \\
\text { posters, website. Internet } \\
\text { advertising and } \\
\text { organization of } \\
\text { competitions. }\end{array}$ & \\
\hline \multicolumn{2}{|c|}{$\begin{array}{l}\text { Cost Structure } \\
\text { - Costs with consolidation, rehabilitation and equipment } \\
\text { of the spaces. } \\
\text { - Costs with the purchase of high-tech devices. } \\
\text { - Staffing and training costs. } \\
\text { - Costs with the promotion and maintenance of the } \\
\text { spaces. }\end{array}$} & \multicolumn{3}{|c|}{$\begin{array}{l}\text { Revenue Streams } \\
\text { - Revenue from ticket sales. } \\
\text { - Proceeds from the sale of souvenirs. } \\
\text { - Revenues from the realization of customized } \\
\text { circuits. } \\
\text { - Income obtained by organizing events (parties. } \\
\text { teambuilding, etc.). }\end{array}$} \\
\hline
\end{tabular}

Fig. 3. Canvas Business Model for Petrila Theme Park

Community-based tourism is a form of local tourism, owned and managed by the community and the development of a community-based tourism model requires the active participation of the community where the development process takes place. Despite the multitude of existing studies in the literature both in relation to community-based tourism and on the evaluation of the models used, there is no analysis of the levers and barriers in its realization.

Although this activity will not be able to compensate for lost jobs, it is difficult to replace an entire industry, it can be the starting point for investments, small businesses, new jobs, but without allowing the emergence of imbalances due to economic growth. uncontrolled.

\section{Conclusions}

Tourism can develop and grow only when the locals have a positive attitude towards it, finding their role in this process. When a tourist destination is born, the quality of life of the locals undergoes radical changes and the attitude of the host community regarding the development of tourism is one of the most important indicators to consider in this process.

Community-based tourism has often been cited as an alternative to mass tourism and an approach to making tourism sustainable. Well-implemented can become a mechanism for reducing poverty and improving the quality of life, providing economic, social and environmental benefits to both locals and communities.

Discovering the existing potential in the tourism industry and approaching it in theory is one of the secrets of conceptualizing innovative business models. Regardless of the large number of perspectives offered and the large number of elements identified in terms of the composition of the business model, it seems that the existing approaches fail to cover the real needs of tourism practices. Therefore, when it comes to tourism, especially industrial tourism, specific characteristics that define the industry indicate the need to redefine the concept of business model and its elements. 
The results obtained, based on the detailed studies within the research, support the business model based on community, proposed, for the Petrila Theme Park. While the technical-economic study shows us that the former mining perimeter is stable and can be used for tourism activities, the social study shows the availability of the population to achieve this transformation, the locals wanting to take part in the process. The most important achievements in community-based tourism are community participation in the entire development process, redistribution of economic benefits, mainly among locals, environmental conservation and, last but not least, conservation of local culture.

\section{References}

1. R., Salvador, J., Lúcio, \& J., Ferreira, Revista Portuguesa de Estudos Regionais, 25-26, (2011)

2. J.A., Domínguez-Gomez. \& T., Gonzalez-Gomez, Elsevier, New York, (2017)

3. S., Stetic \& D., Simicevic, Bulletin of the Serbian Geographical Society, 88/4, (2008)

4. S.S., Hassan, Journal of Travel Research, 28, (2000)

5. H., Dewhurst \& R., Thomas, Journal of Sustainable Tourism, 11(5), (2003)

6. E., Ostrom, Cambridge, University Press, (1990)

7. WCED, Oxford University Press, (1987)

8. T., Huybers, \& J., Bennett, Cheltenham, UK: Edward Elgar Publishing, (2002)

9. C.P., Tang, \& S.Y., Tang, Environment and Planning A: Economy and Space, 38, (2006)

10. R., Curiazi, Journal of Tourism, Culture and Territorial Development, AlmaTourism, 5, (2012)

11.S., Timur \& D., Getz, Sustainable Development, 17(4), (2009)

12. H., Bressers. \& V., Dinica, Environmental Engineering and Management: Sustainable production and consumption, 8(5), (2009)

13. N., Beaumont \& D., Dredge, Journal of Sustainable Tourism 18(1), (2010)

14. T., Donaldson \& L.E. Preston, The Academy of Management Review, 20 (1), (1995)

15. M.B.E., Clarkson, The Academy of Management Review, 20(1), (1995)

16. B.W., Ritchie \& A., Inkari, International Journal of Tourism Research, 8 (1), (2006)

17. D., Gursoy, C., Jurowski \& M., Uysal, Annals of Tourism Research 29(1), (2002)

18. M., Herciua \& C., Ogreana, Procedia Economics and Finance, 16, (2014)

19. N.M.P., Bocken, S.W., Short, P., Rana \&S., Evans, Journal of Cleaner Production, 65, (2014)

20. A., Pateli \& G., Giaglis, European Journal of Information Systems, 13, (2004)

21. M.S., Shafer, H.J. Smith \& J.C., Linde, Business Horizons, 48(3), (2005)

22. C., Baden-Fuller \& V., Mangematin, Strategic Organization, 11(4), (2013)

23. A., Osterwalder \& Y., Pigneur, Chichester, UK, (2010)

24. F., Cosenz \& G.A., Noto, Long Range Plan, 51, (2017)

25. H., Mintzberg, Academy of Management Review, 9, (1984)

26. L., Rayman-Bacchus. \& A., Molina, Futures, 33(7), (2001)

27. M.A., Kabir, K., Jahan, N., Adnan. \& N., Khan, International Journal of Computer and Information Technology, 3(1), (2012)

28. A., Mosleh, S., Nosratabadi. \& P., Bahrami, International Business Research, 8(2), (2015)

29. Y., Ping, International Forum on Information Technology and Applications (2010)

30. Jiu Valley National Mine Closure Company S.A., Management activity report, second semester, 2018

31. I., Samuil, I., Caramidaru \& A.C., Ionică, MATEC Web of Conferences 305(4), (2020)

32. A.C., Ionică, I., Samuil, M., Leba \& M., Toderas, Sustainability, 12, (2020)

33. D.W., Ko, \& W.P., Stewart, Tourism Management, 23, (2002)

34. A., Vargas-Sanchez \& N., Porras-Bueno, Journal Travel Research,. 47, (2008)

35. J.C., Nunnally \& I.H., Bernstein, Psychometric Theory, 3, (1994)

36. E., Cater, Tourism Management, 14 (2), (1993)

37. A., Giampiccoli \& O., Mtapuri, South African Geographical Journal, 98(1), (2012)

38. N., Kontogeorgopoulos, A., Churyen \& V., Duangsaeng, Tourism Planning \& Development, (2014)

39. E., Ruiz-Ballesteros, Tourism Management 32(3), (2011) 